\title{
Digestible threonine-to-lysine ideal ratio for laying hens fed with low-protein diets from 24 to 40 weeks of age
}

\author{
Relação treonina: lisina digestíveis em rações com baixo nível de proteína bruta \\ para galinhas poedeiras leves de 24 a 40 semanas de idade \\ Silvana Marques Pastore $^{I^{*}}$ Luiz Fernando Teixeira Albino ${ }^{I}$ Paulo Cezar Gomes ${ }^{\mathrm{I}}$ \\ Will Pereira de OliveiraII Gabriel da Silva Viana ${ }^{I}$ Eliane Aparecida da Silva \\ Warley Junior Alves ${ }^{I}$
}

\section{ABSTRACT}

This trial was performed to determine the dietary digestible threonine-to-lysine (dig. Thr-to-Lys) ideal ratio for laying hens fed with low-protein diets from 24 to 40 weeks of age. At 24 weeks of age, two hundred forty Hy Line W-36 laying hens were randomly assigned to five treatments, represented by five dig Thr-to-Lys ratios (60; 67; 74; 81 and 88\%), with eight replicates each one with six hens per experimental unit. Digestible Thr-to-Lys did not affect laying hen performance and egg quality, except for digestible Threonine intake, which showed linear increase as dig. Thr-to-Lys ratios increased. Linear broken-line model was chosen to analyze data according to lack of fit. According to linear brokenlinen estimates, digestible Threonine ideal levels for optimum egg production, egg mass, feed efficiency of lysine utilization for egg mass, feed conversion per egg mass and dozens of eggs and nitrogen balance were 0.610; 0.580; 0.614; 0.599; 0.599 and $0.643 \%$, which correspond respectively to dig Thr-to-Lys ratios of $80 ; 75 ; 80 ; 78 ; 78$ and $83 \%$. The digestible threonine-to-lysine ideal ratio for laying hens from 24 to 40 weeks of age is $80 \%$.

Key words: amino acids, performance, egg quality, ratios among amino acids.

\section{RESUMO}

Este estudo foi realizado para determinar a relação ideal de treonina:lisina digestiveis em rações com baixo nível de proteina bruta para galinhas poedeiras leves de 24 a 40 semanas de idade. Utilizaram-se 240 poedeiras Hy Line $W$-36 distribuidas em delineamento inteiramente casualizado, com cinco relações treonina:lisina digestiveis (60; 67; 74; 81 e 88\%), oito repetições e seis aves por unidade experimental. As relações treonina:lisina digestiveis não influenciaram o consumo de ração e de lisina; peso médio dos ovos e seus componentes; ganho de peso e peso corporal final das aves, mas houve efeito linear para o consumo de treonina. $O$ modelo Linear Response Plateau (LRP) foi o que melhor representou a distribuição dos dados para taxa de postura; massa de ovos; eficiência de utilização da lisina por massa; conversão alimentar por massa e por dúzia de ovos; e balanço de nitrogênio. Os platôs ocorrem nos niveis de treonina de 0.61; 0.580; 0.614; 0.599; 0.599 e 0.643\%, que corresponde às relações treonina:lisina digestiveis de 80; 75; 80; 78; 78 e 83\%, respectivamente. A relação ideal de treonina:lisina digestiveis em rações para galinhas poedeiras leves de 24 a 40 semanas de idade é de $80 \%$.

Palavras-chave: aminoácido, desempenho, qualidade de ovo, relação aminoacídica.

\section{INTRODUCTION}

Imbalance in dietary amino acids supply may implicate animal performance beyond enhancing spent of energy and amino acids, such as glycine and serine, to eliminate excessive nitrogen by poultry organism, which when excreted into environment may contaminate soil and hydric resources. The establishment of ideal amino acids profile to meet poultry physiological demand has allowed poultry nutritionist to reduce crude protein by adding crystalline amino acids to diets, which contribute to reduce nitrogen pollution into environment.

Among essential amino acids, threonine (Thr) compound the profile of amino acids demanded by poultry. Its importance in mucins synthesis in gut, antibodies and uric acid formation, besides its presence in body and egg proteins become

\footnotetext{
IDepartmento de Zootecnia, Universidade Federal de Viçosa (UFV), 36570-900, Viçosa, MG, Brasil. E-mail: silvanazoo@hotmail.com. ${ }^{*}$ Corresponding author.

IIInstituto Federal Fluminense (IFF), Bom Jesus do Itabapoana, RJ, Brasil. 
threonine indispensable to maintain adequate poultry metabolism. Dietary digestible threonine and its ideal ratio with lysine optimize Thr utilization consequently resulted in optimum laying hens performance. According to SÁ et al. (2007), Thr requirement for Lohmann hens from 34 to 50 weeks of age is $583 \mathrm{mg}$ bird $^{-1}$ day $^{-1}$, which corresponded to the ratio with lysine in digestible basis of $70 \%$.

As described in Brazilian Tables for Poultry and Swine, ROSTAGNO et al. (2011) suggested that dig. Thr-to-Lys ideal ratio and Thr requirement for white laying hens with egg mass of $55.50 \mathrm{~g}$ is respectively $76 \%$ and $610 \mathrm{mg} \mathrm{bird}^{-1}$ day $^{-1}$; whereas, according to ROCHA et al. (2013) such ratio for Hy Line W-36 laying hens from 24 to 40 weeks of age is $77.60 \%$.

Considering the discrepancies among published results and the importance of Thr for poultry production as well as the establishment of its ratio with lysine in digestible basis, this study was performed to determine the dig. Thr-to-Lys ideal ratio for laying hens fed with low-protein diets from 24 to 40 weeks of age.

\section{MATERIALS AND METHODS}

At 24 weeks of age, two hundred forty Hy-Line W-36 laying hens with average body weight and egg production rate of $92.80 \%$ were randomly assigned to five treatments with eight replicates each one and six hens per experimental unit. Experimental units consisted of three $25 \times 40 \times 45 \mathrm{~cm}$ metal cages, where two hens were allotted, totalizing six hens. Treatments consisted of diets formulated with five digestible Thr levels $(0.461 ; 0.515 ; 0.622$ and $0.676 \%)$, to obtain five dig. Thr-to-Lys ratios $(60 ; 67 ; 74 ; 81$ and $88 \%)$. Dietary digestible Thr levels were obtained through the graded replacement of L-Glutamic by L-Threonine in basal diet.

Basal diet (Table 1) was formulated with $0.461 \%$ of digestible $\mathrm{Thr}, 0.768 \%$ of digestible lysine, $14.26 \%$ of crude protein. Methionine + cysteine, tryptophan, isoleucine, valine, arginine, leucine, histidine and phenylalanine + tyrosine-to lysine ratios in digestible basis considered to formulate basal diet were respectively $103 ; 28 ; 76 ; 96 ; 103 ; 152 ; 44$ and $137 \%$. Dietary digestible lysine was supplied in $90 \%$ of those recommended by ROSTAGNO et al. (2011). Methionine + cysteine, tryptophan, isoleucine and valine-to lysine ratios were met in $103 \%$ of those recommended by BRUMANO et al. (2010), CALDERANO et al. (2012), MELLO et al.
(2012) and ALMEIDA (2014) respectively. Ratios of the other essential amino acids with lysine in digestible basis were supplied, at least, $3 \%$ above the recommended by ROSTAGNO et al. (2011). Such criteria in amino acids supply aimed to guarantee the maximum utilization of lysine and to avoid dietary amino acids deficiency. Thus the ratio between amino acids will represent hen requirement.

All the other nutrients in diets, except Thr and crude protein, were supplied according to ROSTAGNO et al. (2011) nutritional recommendations, considering hen average feed intake of $95 \mathrm{~g} \mathrm{bird}^{-1}$. Diets were daily supplied at 8 and 16h. During the experimental trial, hens had free access to diets and water. Lightning program consisted of supply of $17 \mathrm{~h}$ of light a day. Temperature inside the experimental facility were recorded at $16 \mathrm{~h}$, by two thermometers birds-height placed.

Variables assessed were: egg production; egg weight; egg mass; feed intake; threonine and lysine intake; efficiency of lysine utilization per egg mass produced; feed conversion per egg mass and dozens of eggs; albumen, yolk and eggshell weight and percentage; final body weight and body weight gain; and nitrogen balance.

Nitrogen balance was estimated through excreta total collection. At 40th week, excreta samples from four replicates of each treatment were collected during three days and stored at freezer. Excreta and experimental diets nitrogen content were analyzed according to Kjeldahl method description. Nitrogen balance (\%), expressed in dry matter was obtained through division of total nitrogen retained by total nitrogen ingested.

After analyses of variance (ANOVA) data were analyzed using polynomial and/or linear broken-line regression. Data were analyzed using $\mathrm{R}$ software package (R Development Core Team, 2009) and significant effects were considered when $\mathrm{P}<0.05$.

\section{RESULTS AND DISCUSSION}

Minimum and maximum temperature recorded inside the experimental facility during the trial was respectively $19 \pm 2$ and $31 \pm 2^{\circ} \mathrm{C}$. According to HyLine W-36 guideline (HY LINE W36, 2015), the hen thermal comfort zone is $18-25^{\circ} \mathrm{C}$. Thus, considering the temperature recorded inside the facility, the hens were exposed to periods of heat stress.

Laying hen performance was affected by dig. Thr-to-Lys ratios (Table 2). Egg production showed a liner and linear broken-line response as dig. Thr-toLys ratios increased according to regression equations: 
Table 1 - Composition and nutritional value of experimental diets.

\begin{tabular}{|c|c|c|c|c|c|}
\hline \multirow{2}{*}{ Ingredients (\%) } & \multirow[b]{2}{*}{60} & \multirow[b]{2}{*}{67} & \multirow[t]{2}{*}{ Thr-to-Ly } & \multirow[b]{2}{*}{81} & \multirow[b]{2}{*}{88} \\
\hline & & & & & \\
\hline Corn & 65.793 & 65.793 & 65.793 & 65.793 & 65.793 \\
\hline Soybean meal (45\%) & 18.034 & 18.034 & 18.034 & 18.034 & 18.034 \\
\hline Limestone & 10.226 & 10.226 & 10.226 & 10.226 & 10.226 \\
\hline Soybean oil & 2.405 & 2.405 & 2.405 & 2.405 & 2.405 \\
\hline Dicalcium phosphate & 1.280 & 1.280 & 1.280 & 1.280 & 1.280 \\
\hline Salt & 0.555 & 0.555 & 0.555 & 0.555 & 0.555 \\
\hline Potassium carbonate & 0.161 & 0.161 & 0.161 & 0.161 & 0.161 \\
\hline Choline chloride & 0.020 & 0.020 & 0.020 & 0.020 & 0.020 \\
\hline Vitamin premix ${ }^{1}$ & 0.100 & 0.100 & 0.100 & 0.100 & 0.100 \\
\hline Mineral premix ${ }^{2}$ & 0.050 & 0.050 & 0.050 & 0.050 & 0.050 \\
\hline Antioxidant $^{3}$ & 0.010 & 0.010 & 0.010 & 0.010 & 0.010 \\
\hline DL- methionine (99\%) & 0.404 & 0.404 & 0.404 & 0.404 & 0.404 \\
\hline L-lysine $\mathrm{HCl}(78 \%)$ & 0.232 & 0.232 & 0.232 & 0.232 & 0.232 \\
\hline L-tryptophan (98\%) & 0.083 & 0.083 & 0.083 & 0.083 & 0.083 \\
\hline L-valine (98\%) & 0.166 & 0.166 & 0.166 & 0.166 & 0.166 \\
\hline L-isoleucine $(99 \%)$ & 0.081 & 0.081 & 0.081 & 0.081 & 0.081 \\
\hline L-threonine $(98 \%)$ & 0.000 & 0.060 & 0.119 & 0.178 & 0.237 \\
\hline L-glutamic (99\%) & 0.395 & 0.312 & 0.231 & 0.150 & 0.068 \\
\hline Inert $^{4}$ & 0.005 & 0.028 & 0.050 & 0.072 & 0.095 \\
\hline Total & 100.000 & 100.000 & 100.000 & 100.000 & 100.000 \\
\hline Crude protein $(\%)$ & 14.260 & 14.260 & 14.260 & 14.260 & 14.260 \\
\hline Metabolizable energy $(\mathrm{kcal} / \mathrm{Kg})$ & $2, .900$ & 2,900 & 2,900 & 2,900 & 2,900 \\
\hline Calcium (\%) & 4.232 & 4.232 & 4.232 & 4.232 & 4.232 \\
\hline Non-phytate phosphorous (\%) & 0.316 & 0.316 & 0.316 & 0.316 & 0.316 \\
\hline Sodium $(\%)$ & 0.237 & 0.237 & 0.237 & 0.237 & 0.237 \\
\hline Potassium (\%) & 0.611 & 0.611 & 0.611 & 0.611 & 0.611 \\
\hline Dig. lysine (\%) & 0.768 & 0.768 & 0.768 & 0.768 & 0.768 \\
\hline Dig. methionine + cysteine $(\%)$ & 0.791 & 0.791 & 0.791 & 0.791 & 0.791 \\
\hline Dig. arginine (\%) & 0.796 & 0.796 & 0.796 & 0.796 & 0.796 \\
\hline Dig. phenylalanine + tyrosine $(\%)$ & 1.055 & 1.055 & 1.055 & 1.055 & 1.055 \\
\hline Dig. histidine (\%) & 0.340 & 0.340 & 0.340 & 0.340 & 0.340 \\
\hline Dig. leucine (\%) & 1.168 & 1.168 & 1.168 & 1.168 & 1.168 \\
\hline Dig. isoleucine $(\%)$ & 0.584 & 0.584 & 0.584 & 0.584 & 0.584 \\
\hline Dig. threonine (\%) & 0.461 & 0.515 & 0.569 & 0.622 & 0.676 \\
\hline Dig. tryptophan (\%) & 0.215 & 0.215 & 0.215 & 0.215 & 0.215 \\
\hline Dig. valine (\%) & 0.737 & 0.737 & 0.737 & 0.737 & 0.737 \\
\hline
\end{tabular}

${ }^{1}$ Vitamin premix - Composition $\mathrm{kg}^{-1}$ : vit. A - 7.200.000U.I. vit. $\mathrm{D}_{3}-1.600 .000$ U.I. vit. $\mathrm{E}-5.000 \mathrm{mg}$. vit. $\mathrm{B}_{1}-900 \mathrm{mg}$. vit. $\mathrm{B}_{2}-2.700 \mathrm{mg}$. vit. $\mathrm{B}_{6}-1.500 \mathrm{mg}$. vit. $\mathrm{B}_{12}-7.200 \mathrm{mg}$. pantothenic acid $-5.900 \mathrm{mg}$. vit. $\mathrm{K}_{3}-1.100 \mathrm{mg}$. folic acid $-250 \mathrm{mg}$. niacine $-16.200 \mathrm{mg}$. selenium $250 \mathrm{mg}$. antioxidant additive $-250 \mathrm{mg} ;{ }^{2}$ Mineral premix - Composition $\mathrm{kg}^{-1}$ : manganese $-100.000 \mathrm{mg}$. iron- $60.000 \mathrm{mg}$. zinc $-800.000 \mathrm{mg}$. copper $-12.000 \mathrm{mg}$. iodine $-1.000 \mathrm{mg}$. selenium $-300 \mathrm{mg} ;{ }^{3}$ tert-butyl-4-hydroxy toluene (BHT); ${ }^{4}$ sand. 
Table 2 - Performance and nitrogen balance of White laying hens from 24 to 40 weeks of age fed different digestible Thr-to-Lys ratios.

\begin{tabular}{|c|c|c|c|c|c|c|c|}
\hline \multirow{2}{*}{ Variable } & \multicolumn{5}{|c|}{------------Digestible Thr-to-Lys ratio (\%)----------- } & \multirow{2}{*}{ CV $(\%)$} & \multirow{2}{*}{ P-value } \\
\hline & 60 & 67 & 74 & 81 & 88 & & \\
\hline Egg production $(\%)^{1.2}$ & 90.81 & 91.80 & 92.32 & 94.32 & 93.79 & 2.09 & 0.005 \\
\hline Egg weight (g) & 59.47 & 59.80 & 59.23 & 59.63 & 58.50 & 2.31 & 0.725 \\
\hline Egg mass $\left(\mathrm{g} \mathrm{bird}^{-1} \text { day }^{-1}\right)^{1.2}$ & 53.96 & 54.84 & 54.79 & 56.23 & 55.43 & 2.23 & 0.012 \\
\hline Feed intake $\left(\mathrm{g} \mathrm{bird}^{-1}\right.$ day $\left.^{-1}\right)$ & 94.13 & 93.98 & 91.98 & 93.03 & 92.05 & 2.47 & 0.200 \\
\hline Threonine intake $\left(\mathrm{mg} \mathrm{bird}^{-1} \text { day }^{-1}\right)^{1}$ & 433.95 & 483.99 & 523.36 & 578.66 & 622.25 & 2.39 & $<0.001$ \\
\hline Lysine intake (mg bird ${ }^{-1}$ day $^{-1}$ ) & 722.94 & 721.76 & 706.37 & 714.49 & 706.93 & 2.47 & 0.200 \\
\hline Efficiency of lysine utilization per egg mass $\left(\mathrm{g} \mathrm{g}^{-1}\right)^{1.2}$ & 74.67 & 75.99 & 77.75 & 78.76 & 78.23 & 2.10 & $<0.001$ \\
\hline Feed conversion $\left(\mathrm{kg} \mathrm{dozen}^{-1}\right)^{1.2}$ & 1.25 & 1.23 & 1.20 & 1.18 & 1.18 & 2.92 & 0.001 \\
\hline Feed conversion $\left(\mathrm{kg} \mathrm{kg}^{-1}\right)^{1.2}$ & 1.75 & 1.72 & 1.68 & 1.66 & 1.67 & 1.98 & $<0.001$ \\
\hline Body weight gain $\left(\mathrm{g}\right.$ bird $\left.^{-1}\right)$ & 54 & 88 & 78 & 90 & 69 & 44.75 & 0.213 \\
\hline Final body weight $\left(\mathrm{kg} \mathrm{bird}^{-1}\right)$ & 1.50 & 1.54 & 1.52 & 1.55 & 1.52 & 2.23 & 0.098 \\
\hline Nitrogen balance $(\%)^{1.2}$ & 53.98 & 55.88 & 58.06 & 59.01 & 62.65 & 5.79 & 0.024 \\
\hline
\end{tabular}

$\mathrm{CV}=$ coefficient of variation; $1=$ linear effect; $2=$ linear broken-line effect.

$\hat{\mathrm{Y}}=83.6453+15.7605 \mathrm{x}, \mathrm{r}^{2}=86.49$ e $\hat{\mathrm{Y}}=81.1851+$ $20.5386 x, r^{2}=92.96$, respectively. According to linear broken-line equations, the digestible Thr level from which the plateau was observed was $0.613 \%$, which corresponds to dig. Thr-to-Lys ratio of $80 \%$ and egg production rate of $93.78 \%$.

Digestible Thr-to-Lys ideal ratio estimated for optimum egg production $(80 \%)$ in this trial was greater than the one determined by ROCHA et al. (2013), who established the dig. Thr-to-Lys ratio of $78 \%$ as ideal for Hy-Line W-36 laying hens at the same age. The greater Thr need reported in this trial compared to those observed by ROCHA et al. (2013) may be justified by the higher egg production rate observed in this trial $(93.78 \%)$ compared to the authors $(84.42 \%)$. The average egg production in this trial was $92.60 \%$, which is approximately $1 \%$ inferior to the recommended by the genetic line guideline (HY LINE W36, 2015). Although the difference in egg production is narrow, it is important to observe that experimental diets were formulated to provide a sub-marginal digestible lysine supply, once this trial was performed to determine the dig. Thr-to-Lys ideal ratio for optimum laying hen performance and egg quality; and the establishment of such ratio and digestible lysine requirement allowed to determine ideal digestible $\mathrm{Thr}$ level in diets.

Egg weight was not influenced $(\mathrm{P}>0.05)$ by dietary dig. Thr-to-Lys ratios. Linear and linear broken-line $(\mathrm{P}<0.05)$ regression effects was verified for egg mass production as dietary dig. Thr-to-Lys increased, as described by the following regression equations: $\hat{\mathrm{Y}}=50.4717+8.05188 \mathrm{x}, \mathrm{r}^{2}=66.28$ e $\hat{\mathrm{Y}}$
$=48.1656+12.5306 \mathrm{x}, \mathrm{r}^{2}=85.87$, respectively. The plateau was estimated from dig. Thr-to-Lys ratio of $75 \%$, which corresponded to egg mass value of $55.43 \mathrm{~g} \mathrm{bird}^{-1} \mathrm{day}^{-1}$. The increasing observed in egg mass values in dig. Thr-to-Lys are expected, once egg production increased, whereas egg weight was not affected by diets (Table 2). Similarly, SÁ et al. (2007) and LELIS (2010) did not observe effects of dig. Thr-to-Lys ratios on egg weight. However, authors reported dig. Thr-to-Lys optimum ratios for egg mass of 72 and $72.7 \%$ respectively.

The dig. Thr-to-Lys ratio of $75 \%$ is similar to those described by ROSTAGNO et al. (2011), which recommended the dig. Thr-to-Lys of $76 \%$ for laying hens with egg mass production of $55 \mathrm{~g} \mathrm{bird}^{-1}$ day $^{-1}$. However, comparing the $\mathrm{Thr}$ requirement determined in this trial $\left(535 \mathrm{mg}\right.$ bird $^{-1}$ day $\left.^{-1}\right)$ with those described by ROSTAGNO et al. (2011) (610mg bird $^{-1}$ day $\left.^{-1}\right)$, it is observed that hens in the current trial presented higher efficiency, once they presented lower feed intake (75mg bird ${ }^{-1}$ day $^{-1}$ less Thr) and produced equivalent egg mass $\left(55 \mathrm{~g} \mathrm{ave}^{-1} \mathrm{dia}^{-1}\right)$.

Average daily intake in this trial was $93 \mathrm{~g}$ bird $^{-1}$, which close to feed intakes recommended by genetic line guideline $\left(92 \mathrm{~g} \mathrm{bird}^{-1}\right.$ day $\left.^{-1}\right)$ (HY LINE W36, 2015). Thus, heat stress during the trial did not affect feed intake. Digestible Thr-to-Lys ratios did not influence hen feed intake $(\mathrm{P}>0.05)$. Such result is in agreement with published reports (SÁ et al., 2007; LELIS, 2010) and indicated that laying hens are not capable of regulating Thr deficiency through enhancing in feed intake (MARTÍNEZ-AMESCUA et al., 1999). 
Threonine intake enhanced linearly $(\mathrm{P}<0.05)$ as dietary dig. Thr-to-Lys ratio increased, as demonstrated by the following regression equation: $\hat{Y}$ $=29.5080+877.481 \mathrm{x}, \mathrm{r}^{2}=99.78$. Such behavior of response is justified by linear increasing in dietary Thr supply to obtain dig. Thr-to-Lys ratios; and no effects of dig. Thr-to-Lys ratios on laying hen feed intake.

Digestible lysine intake was not affected by experimental diets $(\mathrm{P}>0.05)$, which is expected, once lysine in experimental diets, were equally supplied and feed intake was not influenced by dig. Thr-to-Lys ratios. However, it was observed linear and linear broken-line $(\mathrm{P}<0.05)$ effects on efficiency of lysine utilization per egg mass, as described by regression equations: $\hat{\mathrm{Y}}=66.5893+18.4495 \mathrm{x}$, $\mathrm{r}^{2}=84.47$ e $\hat{\mathrm{Y}}=62.6163+26.1657 \mathrm{x}, \mathrm{r}^{2}=99.13$, respectively. The plateau in laying hen responses was observed from Thr level of $0.614 \%$ on, which corresponds to dig. Thr-to-Lys ratio of $80 \%$ and the value of $78.23 \mathrm{~g} \mathrm{~g}^{-1}$.

The efficiency of lysine utilization per egg mass is an important measure, once it isolates the effect of the amino acids studied on hen performance, specifically when treatments influence feed intake and lysine intake. Such variable allows identifying in which treatment the lower amount of lysine was used to produce one gram of egg mass. In the current trial, the greater efficiency of lysine utilization was obtained with the dig. Thr-to-Lys ratio of $80 \%$.

Feed conversion per egg mass $\left(\mathrm{kg} \mathrm{kg}^{-1}\right)$ and per dozen $\left(\mathrm{kg}\right.$ dozen $\left.^{-1}\right)$ reduced linearly $(\mathrm{P}<0.05)$ when dig. Thr-to-Lys ratios increased, as described by the regression equations: $\hat{\mathrm{Y}}=1.92623-0.409749 \mathrm{x}$, $\mathrm{r}^{2}=85.14$ e $\hat{\mathrm{Y}}=1.39048-0.323566 \mathrm{x}, \mathrm{r}^{2}=85.84$; respectively. Linear broken-line $(\mathrm{P}<0.05)$ effect of dig. Thr-to-Lys ratios was observed on feed conversion per egg mass $\left(\mathrm{kg} \mathrm{kg}^{-1}\right)$ and per dozen $(\mathrm{kg}$ dozen $^{-1}$ ), as described by the equations: $\hat{\mathrm{Y}}=62.6163$ $+26.1657 \mathrm{x}, \mathrm{r}^{2}=99.13$ e $\hat{\mathrm{Y}}=1.45401-0.446944 \mathrm{x}$, $\mathrm{r}^{2}=97.99$. The plateau for feed conversion per egg mass and per dozen of eggs were both obtained from the dig. Thr-to-Lys ratio of $78 \%$, which corresponds to Thr level of $0.599 \%$ and which resulted in feed conversion per egg mass and dozen of eggs values of $1.66 \mathrm{~kg} \mathrm{~kg}^{-1}$ and $1.18 \mathrm{~kg} \mathrm{dz}^{-1}$, respectively.

ROCHA et al. (2013) observed improvement in feed conversion per egg mass and dozen of eggs values with dig. Thr-to-Lys ratios of 75 e $77.60 \%$, respectively. SÁ et al. (2007) verified better values of feed conversion per dozen of eggs with dig. Thr-to-Lys ratio of $72 \%$. Although the lower dig. Thr-to-Lys ratio observed by the authors, compared with the ideal ratio determined in the current trial (78\%), the Thr intake estimated by SA et al. (2007) was greater than the observed in this trial (583 x 555mg bird $\left.{ }^{-1}\right)$. Such difference is due to bird daily feed intake, which in this trial was $93 \mathrm{~g} \mathrm{bird}^{-1}$, whereas SÁ et al. (2007) observed $114 \mathrm{~g} \mathrm{bird}^{-1}$. In both trials, dig. Thr-to-Lys ideal ratio were determined with white laying hens.

The dig. Thr-to-Lys ratios was not observed $(\mathrm{P}>0.05)$ on final body weight and hen weight gain (Table 2). However, the hens were fed with diets containing sub-marginal level of lysine, which could have influenced weight gain and final body weight. Linear and linear broken-line effects of dietary dig. Thr-to-Lys ratios $(\mathrm{P}<0.05)$ were observed on nitrogen balance (Table 2), as described by the equations: $\hat{Y}$ $=36.2349+38.1268 \mathrm{x}, \mathrm{r}^{2}=96.90$ e $\hat{\mathrm{Y}}=36.5098+$ $37.789 x, r^{2}=99.84$, respectively. The plateau was established from the Thr level of $0.643 \%$, which corresponds to dig. Thr-to-Lys ratios of $83.70 \%$ and nitrogen balance of $60.82 \%$.

Similar behavior was observed in nitrogen balance and egg production responses. The plateau for egg production rate was established from the dig. Thr-to-Lys ratio of $80 \%$; whereas, the same response for nitrogen balance was observed from the ratio of $83.70 \%$. Thus, it was possible to conclude that greater egg production rate requires greater nitrogen amount to maintain egg protein synthesis, which is obtained from dietary supply. Thus, less nitrogen is excreted, which impacts positively in nitrogen balance.

MATOS et al. (2009) did not observe influence of dietary Thr levels $(0.50 ; 0.55$ e $0.60 \%)$ on laying hen nitrogen balance at 44 weeks of age, as well as on hen egg production from 25 to 44 weeks of age. Digestible Thr-to-Lys ratios did not affect $(\mathrm{P}>0.05)$ albumen, yolk and eggshell weight and percentage (Table 3 ). Such results are in agreement with those observed in egg weight. Thus, the dig. Thr-to-Lys ratio of $60 \%$, which corresponds to digestible Thr intake of $434 \mathrm{mg} \mathrm{bird}^{-1}$, maintaining adequate egg quality of white laying hens from 24 to 40 weeks of age.

ROCHA et al. (2013), as well as observed in this trial, did not observe effects of dietary dig. Thrto-Lys ratios on albumen, yolk and eggshell weight and percentage for white laying hens from 24 to 40 weeks of age. Though KAKIMOTO et al. (2014) who studied dig. Thr-to-Lys ratios for brown laying hens from 26 to 42 weeks of age, observed that digestible Thr levels of 0.65 and $1.1 \%$ resulted in greater and lower yolk percentage and lower and greater albumen percentage respectively. 
Table 3 - Egg quality of laying hens from 24 to 40 weeks of age fed with different digestible Thr-to-Lys ratios.

\begin{tabular}{|c|c|c|c|c|c|c|c|}
\hline \multirow{2}{*}{ Variables $^{1}$} & \multirow[b]{2}{*}{60} & \multirow[b]{2}{*}{67} & \multirow[b]{2}{*}{74} & \multirow[b]{2}{*}{81} & \multirow[b]{2}{*}{88} & \multirow{2}{*}{ CV (\%) } & \multirow{2}{*}{ P-value } \\
\hline & & & & & & & \\
\hline Albumen (g) & 38.79 & 39.05 & 38.30 & 38.74 & 38.40 & 0.76 & 0.383 \\
\hline Yolk (g) & 15.74 & 15.85 & 15.70 & 15.56 & 15.58 & 2.00 & 0.501 \\
\hline Eggshell (g) & 5.55 & 5.61 & 5.48 & 5.60 & 5.45 & 2.58 & 0.386 \\
\hline Albumen (\%) & 64.59 & 64.56 & 64.42 & 64.72 & 64.60 & 0.76 & 0.827 \\
\hline Yolk (\%) & 26.18 & 26.17 & 26.38 & 25.93 & 26.21 & 2.00 & 0.583 \\
\hline Eggshell (\%) & 9.23 & 9.27 & 9.21 & 9.35 & 9.19 & 2.58 & 0.678 \\
\hline
\end{tabular}

${ }^{1}$ Non-significant; $\mathrm{CV}=$ coefficient of variation.

\section{CONCLUSION}

The dig. Thr-to-Lys ideal ratio for laying hens fed with low-protein diets from 24 to 40 weeks of age is $80 \%$, which corresponds to the threonine and lysine intake of $571 \mathrm{mg} \mathrm{bird}^{-1}$ day $^{-1}$ and $713 \mathrm{mg}$ bird $^{-1}$ day $^{-1}$ respectively.

\section{BIOETHICS \\ AND COMMITTEE APPROVAL}

BIOSSECURITY

Approved by the ethics commission in use of production animals of Universidade Federal de Viçosa (UFV), under protocol n. 24/2014.

\section{AKNOWLEDGMENTS}

The authors thank the Conselho Nacional de Desenvolvimento Científico e Tecnológico (CNPq) for the scholarship granted and Ajinomoto Biolatina Indústria e Comércio Ltda for the financial support.

\section{REFERENCES}

ALMEIDA, R.L. Relações valina:lisina em rações para poedeiras leves de 24 a 58 semanas de idade. 2014. 75f. Tese (Doutorado em Zootecnia) - Universidade Federal de Viçosa, Viçosa, MG.

BRUMANO, G. et al. Digestible methionine + cystine level in meals for light-weight laying hens from 24 to 40 weeks of age. Revista Brasileira de Zootecnia, v.39, p.1228-1236, 2010. Available from: <http://www.scielo.br/pdf/rbz/v39n6/10.pdf $>$. Accessed: Feb. 12, 2015. doi: 10.1590/S1516-35982010000600010.

CALDERANO, A.A. et al. Digestible tryptophan: digestible lysine ratio in diets for laying hens from 24 to 40 weeks of age. Revista Brasileira de Zootecnia, v.41, p.2176-2182, 2012. Available from: $<$ http://www.scielo.br/pdf/rbz/v41n10/v41n10a06.pdf >. Accessed: Feb. 10, 2015. doi: 10.1590/S1516-35982012001000006.

HY-LINE DO BRASIL. Management Guide: W-36 commercial layers. S.I.: s.n., 2015. 44p. Available from: <http://www.
hyline.com/UserDocs/Pages/36_COM_ENG.pdf>. Accessed: Feb. 07, 2015.

KAKIMOTO, S.K. et al. Qualidade de ovos de poedeiras marrons alimentadas com diferentes níveis de treonina e zinco quelatado. In: CONGRESSO APA - PRODUÇÃO E COMERCIALIZAÇÃO DE OVOS, 12., 2014, Ribeirão Preto, SP. Anais... Ribeirão Preto: Associação Paulista de Avicultura, 2014. CD-ROOM.

LELIS, G.R. Atualização da proteína ideal para poedeiras semipesadas: treonina e valina. 2010. 98f. Tese (Doutorado em Zootecnia) - Universidade Federal de Viçosa, Viçosa, MG.

MARTINEZ-AMEZCUA, C. et al. Dietary L-threonine responses in laying hens. Journal Applied Poultry Research, v.8, p.236241, 1999. Available from: <http://japr.oxfordjournals.org/ content/8/2/236.full.pdf $>$. Accessed: Feb. 18, 2015. doi: 10.1093/ $\mathrm{japr} / 8.2 .236$.

MATOS, M.S. et al. Digestible lysine and threonine levels for Lohmann LSL laying hens from 24 to 44 weeks of age. Acta Scientiarum Animal Science, v.31, p.19-24, 2009. Available from: <http://www.redalyc.org/articulo.oa?id=303126495009>. Accessed: Feb. 13, 2015. doi: 10.4025/actascianimsci. v31i1.1387.

MELLO, H.H.C. et al. Determination of digestible isoleucine:lysine ratio in diets for laying hens aged 42-58 weeks. Revista Brasileira de Zootecnia, v.41, p.1313-1317, 2012. Available from: $<$ http:// www.scielo.br/pdf/rbz/v41n5/32.pdf>. Accessed: Feb. 05, 2015. doi: 10.1590/S1516-35982012000500032.

ROCHA, T.C. Digestible threonine to lysine ratio in diets for laying hens aged 24-40 weeks. Revista Brasileira de Zootecnia, v.42, p.879-884, 2013. Available from: <http://www.scielo.br/ pdf/rbz/v42n12/07.pdf $>$. Accessed: Feb. 08, 2015. doi: 10.1590/ S1516-35982013 001200007.

ROSTAGNO, H.S. et al. Brazilian Tables for Poultry and Swine: Composition of Feedstuffs and Nutritional Requirements. $3^{\text {rd }}$ ed. Viçosa: UFV, 2011. 251p.

SÁ, L.M. et al. Exigência nutricional de treonina digestível para galinhas poedeiras no período de 34 a 50 semanas de idade. Revista Brasileira de Zootecnia, v.36, p.1846-1853, 2007. Available from: $<$ http://www.scielo.br/pdf/rbz/v36n6/a18v36n6.pdf $>$. Accessed: Feb. 09, 2015. doi: 10.1590/S1516-35982007000800016. 